\title{
Leading Edges of Economy-Building Science Education
}

\author{
Akbar Nikkhah* \\ Faculty of Agricultural Sciences, Department of Animal Sciences, University of Zanjan, Iran
}

\begin{abstract}
This article innovatively elaborates on two entirely useful and harmful angles of science education in building growing economy nationally and globally. Static economy-demolishing schooling versus accountable and moral economyflourishing mentorship is delineated from a science edification philosophy. Generating moral figures and perceptions from scientific and educational discoveries must be globally pursued. This is key to maintaining an expanding nature for science-founded economy and to establishing national and international peace and prosperity.
\end{abstract}

\section{Keywords: Science; Education; Economy; Global business; Finance}

\section{Innovative Edges of Science-Founded Economy Policies}

The objective of this economy policy article was to describe innovative edges of science education for quality economy and life in the new postmodern rising era. Science and technology education in the postmodern time will not be counted merely on the basis of practical or purely hypothetical realizations and achievements. The capability to preserve embryonic tendencies in science and technology education will rely on generating the type of scientists and researchers who can capacitate education and creation of more and not less qualified than own.

Such new generations of science and technology educators and mentors are not simply characterized by teaching and research proficiencies [1,2]. They must be crucial edges whose exclusivities are embraced with merits in growth and education of science-founded economy mentorship concepts. Mentorship is an art whereas schooling is a limited occupation. Schooling is transferring knowledge to learners whereas moral mentorship is constructing, capturing and exchanging insights in science and technology. Schooling teaches learning and education of self, but mentorship creates capacities to train and mentor minds and bodies of else $[3,4]$.

From a global perspective, schooling develops learners that finally graduate whereas mentorship generates pragmatic influencers that move on forever in the learning path until after even they bodily die. Schooling requires giving back the teacher only the materials that were educated whereas mentorship directs minds to create innovative philosophies. Schooling is almost a one-way correspondence, but mentorship is an innovative and creative medium for idea and perspective exchange. Schooling does not tolerate mentees to question teachers and the way they think and teach, whereas mentorship truly welcomes pragmatic learners to challenge mentors' thoughts [5-7].

Questions and challenges are the means whereby learners can experience science communication with others and observe critical education of others. Schooling is restricted to habitual times whereas mentorship defines a circadian lifetime commitment [8].

Schoolers are employees whereas mentors serve as employers. Schools employ teachers whereas mentors employ science and technology. Schooling encourages learning whereas mentorship creates mentors capable of building ever evolving education roads. Schoolers tutor science whereas mentors generate innovative science producers. Schooling is an already-known task whereas mentorship is a creative and challenging commitment. The most important results of schooling are science discoveries whereas among the utmost consequences of mentorship are brilliant minds and philosophies that are created within mentors' contemplations towards creating the scientists that fuel ongoing discoveries.

Schooling may expand the existing knowledge somewhat, whereas mentorship does develop scientists who collectively make considerable progress in the innovation of new ground breaking insights. Knowledge is the end but insight is just the inauguration to commence and create novel authorities of contemplation. In a nutshell, schooling is an instant line whereas mentorship is a well-shaped thorough concept of pragmatism that resembles an encircle surrounding a central negligible tip of discoveries. However, the adjacent surrounding area encompasses the morality in creating leading-edge mentors of science education. Certainly, schooling causes knowledge accumulation that conceptually and pragmatically adds nothing to the literature but the complexity, whereas mentorship integrates science into safe and quality economy and life policies.

\section{Conclusions}

To sum, schooling complicates science whereas mentorship simplifies understanding of economy and life. Accountable mentorship instead of irresponsible schooling will persist to serve as a crucial cuttingedge science for today's education towards quality economy and life. Such a pragmatic mentorship will immensely help create global moral figures and concepts from scientific discoveries. These perceptions are a crucial beginning to global cooperations in establishing reciprocal understanding and sturdy national-international peace and prosperity.

\section{Acknowledgment}

The Iran's Ministry of Science Research and Technology, National Elite Foundation, and University of Zanjan are thanked for supporting the author's global initiatives and innovative programs of optimizing science edification in the new millennium.

\section{References}

1. Nikkhah A (2014) Science of the new times: A circle not a line. Adv Crop Sci Tech.

*Corresponding author: Akbar Nikkhah, Chief Highly Distinguished Professor, Faculty of Agricultural Sciences, Department of Animal Sciences, University of Zanjan, Iran, Tel:+98 (24) 33051; E mail: anikkha@yahoo.com

Received May 18, 2015; Accepted June 23, 2015; Published June 30, 2015

Citation: Nikkhah A (2015) Leading Edges of Economy-Building Science Education. J Glob Econ 3: e109. doi:10.4172/2375-4389.1000e109

Copyright: (c) 2015 Nikkhah A. This is an open-access article distributed under the terms of the Creative Commons Attribution License, which permits unrestricted use, distribution, and reproduction in any medium, provided the original author and source are credited. 
2. Nikkhah A (2011) Structuring science education in the new millennium: Authorizing a succeeding integrity. Nova science Publishers.

3. Nikkhah A (2011) Science education of the new millennium: mentorship arts for creative lives. Scientific research.

4. Nikkhah A (2011) The art of science education. Nova Publishers Inc, New York USA.

5. Weinberg S (2011) Nobelist Steven Weinberg Calls for Bigger Science, More Taxes
6. Nikkhah A (2011) Postmodern science edification philosophy. Open Journal of Philosophy 1: 37-38.

7. Nikkhah A (2011) Postmodern governments and science education. Journal of Public Administration and Governance 1: 71-74.

8. Nikkhah A (2015) Global Science Education: Bioprocessing and Brainfueling of Innovation. J Bioprocess Biotechniq. 